\title{
マウスにおける下垂体除去の影響
}

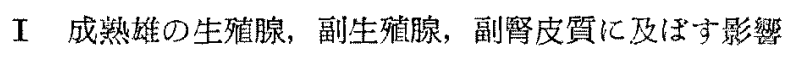

\author{
西田司一・望月公子 \\ (東京大学搌学部)

\section{Influences of hypophysectomy in mouse}

I Effects upon testis, ventral prostate, seminal vesicle and adrenal of adult mouse

SHIICHI NISHIDA and KosHI MochizukI

(Faculty of Agriculture, University of Tokyo)

\section{I 緒言}

従来各種動物に於ける下重体除去の影響の内生殖腺, 副腎については，雄に於ては一般に睪丸並びに副留皮質 特に Zona fasciculata の萎縮が羿められているが，こ の退縮の程度，速さにはかなり動物差があるようである。 マウスに於ける報告は少〈 LEBLOND \& NELSON (137), JoNEs $(149,150)$ 等 2,3 の報告を見るのみであり，本邦に 於ては皆無でする。著者等は下垂体一生殖腺一副堅皮質の 斫究の基礎実験として，マウスに於ける下重体除去後の 生殖腺, 副腎等内分汹腺の経時的变化を追究中であるが, 本報ではこの内成熟雄に関する結果について報告する。

\section{II 材料及方法}

使用動物性当研究室で繁殖解育したbc系マウスで，2 〜 5 ケ月噛の成熟雄30頭である。下垂体除去動物は20頭 で，除去後40日までの活々の期間に屠殺検查した。娰照 動物は同腹兄弟10頭を用いた。組倳は重量測定得值に固 定しだ。固定薬は主しして Boun, ZENKER-formol t用 い, 染色は Hematoxylin-eosin, 要丸では HEIDENHAIN's

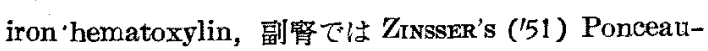
fuchsin の変法を常用した。

下垂体剔出の成否は Sella の部分の連続切片又はルー ペ $(\times 10)$ で肉眼的飞検查し, 少量でも下垂体の残つて いるものは dataから除外した。

\section{III 観祭}

\section{1 肉眼的所見}

睪丸：手術後拿丸は腹腔内に上り，時日の経過之已も に陰䃌，陰蕉は去勢雄のものと区別し難くなり，手術後 15日以内に等丸の触診も困難となる。剖検によると，辠 丸は著しく柔軟となり充実感尼失い，乙の程度経過日
数とともに顕著となる。白膜はやや強鞄となる感があ る。色調舟変化し手術25日以後のものに於ては黄褐色を 带びる。睪丸重量も第 1 表に示す如々，手術後25日以内 に対照の約 $1 / 5$ 以下に減少する。

Table I Table showing the organ weights after hypophysectomy in normal adult male mice

\begin{tabular}{|c|c|c|c|c|c|}
\hline $\begin{array}{l}\text { No. of } \\
\text { animals }\end{array}$ & $\begin{array}{c}\text { Days } \\
\text { after hy- } \\
\text { pophys- } \\
\text { ectomy }\end{array}$ & $\begin{array}{l}\text { Testes } \\
\text { (my) }\end{array}$ & $\underset{(m g)}{\text { Adrenal }}$ & $\begin{array}{l}\text { Ventral } \\
\text { prostate } \\
\text { (mg) }\end{array}$ & $\begin{array}{c}\text { Seminal } \\
\text { vesicle } \\
(\mathrm{mg})\end{array}$ \\
\hline 10 & Control & 117 & & & 243 \\
\hline 5 & $1 \cdots 10$ & 82.3 & 1.2 & 4.6 & 34 \\
\hline 7 & $11 \cdots 20$ & 49.6 & 1.0 & 2.7 & 13.5 \\
\hline 4 & $21 \cdots 30$ & 20. & 0.9 & 1.8 & 6.0 \\
\hline 4 & $31 \cdots 40$ & 14.3 & 0.9 & $(-)$ & 6.25 \\
\hline
\end{tabular}

副珡も肉眼的に褪色, 菱縮, 㳄化し, 手術後の経過日 数とともに周囲の脂肪組織との区別困難となり，额带ル 一ペによつて渐く識別し得る程度となる。萎繀も著明で 感量 $1 \mathrm{mg} の$ ○ーションバランスで位一側每の重量測定 が出来なくなる。

副生殖腺も亦菱樎裉色し, 腹前立腺(Ventral prostate) はその程度甚しく，肉眼的には周用の脂助組織との区別

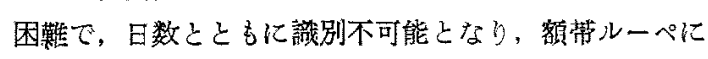
よつても識別因難なものがあつた。かかるものでは完全 な分離採取は困難で, 切片に些てかなりの脂眆組織か附 着しているものがあつた。従つて重量 dataはやや精確 性を久くららみはあるが，次の組織学的観察結果加らむ 重量 data 当変化の大要は示するのと考元られる。精雚 も半透啰となるが肉眼的に識別し得る。分泌物は手術後 10日頃には㪊め得なくなる。

\section{2 組織学的所見}

罢丸：精細管は手術後15２0日頃迄に急速にその口径 を淢し，精上皮の居も薄くなるが，その後の減少はやや 緩徐となり，30日以後では减少程度少々はば一定して来 
る。この管径の娍少に伴い管堙も狭くなり，35日以後の ものに於ては管腔は殆んで見られなくなる(Fig. 6)。

精子は手術後減少するが，汗術後10日頃迄は尚かなり の数の精子が認妨られる(Tin. 2)。手術後15日になれば 精子は殆んど羿められず，稀䎲少数の精紐管内に極く少 数の精子が楒められるに過ざなくなり，之の染色性も搦 くなり (Fig. 3)，20２5日頃迄几完全に精子は全精細 管内から消失する(Figs．4，5)。一方 spermatia 㐘精 子の減少にはぼ平行して減少し街後25日頃迄に消失し，

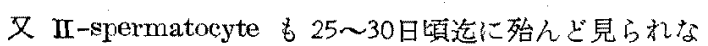
くなる(Fig，5)。この後は I -spermatocyte と spermatogonia が 2〜3 層の薄い精上皮点權成するようになる。 gonia 历びI-cyte には手術40日後に於て当尚分裂像が 認められるが, gonia の一部及び cyte の大部分のもの

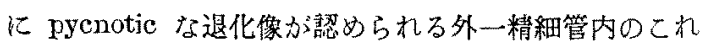
ら精細胞数は著しく減少している。SERTOLI 氏細胞は不 規則な形を示しながらも尚少数その存在が認められる。

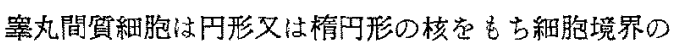
此較的明らかな正常像は下垂体除去後かなり速が失わ れ，手術後 5 日㥧すど变化か認められ，核は不整形で pycnotic なもの, 又 karyorrhexis 様のもの等程々の变 化を示し，細胞潪界も不明膫となつて，iron hematoxylin 亿全体として強く黒染するようになり(Fig. 2), 又手術後長期を経たむのでは精細管の間隐を黑色儿充す ように見兑る(Fig. 4,5)。

副留皮質：下垂体除去後5日目に於てすでに僌度なが ら変化が翟奶られる。Z. glomerulosa に於ては細胞は やや肥大し, $Z$. fasciculata 亿接した部分の細胞に於て 比較的明らかである。核の大きさ構造には明らかな変化 は譛められない。Z. fasciculata 亿於ては細胞はや队 萎縮し，細胞質内の Iipoid 含量专減少する。切片儿於 ける皮質巾もやや堿少するがその主因は fasciculata の 退縮にあるようである(Fig. 8)。以上のようふ変化は手 街後の日数の経過ととも亿進行し，10日以後に於ては fasciculata の所々に cytolysis 或は核に pycnosis 像が 認められるが，SELYE ('53) がラッテで観䋈したような “pseudo-tubular”の变化住羿められない。ある例に於 ては fasciculata の血管の著明な抬張が認められ，血管䧑 内に好塩基性の小顆粒が少数散在するのが忍的られた。

成熟雄で下垂体起除去したものの X-zone は痕跡的 で，遺残細胞は極く少数散在的に琶められるのみで，皮

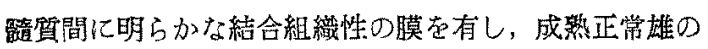
ものに酷似し，同様に遺残細胞の細胞筫は Zenker一 formol 固定ではanilin blue で青染されるが, Ponceaufuchsin 仁よる fuchsin 好染顆粒隹認められ桨い。

手政後 15〜20日以上経過したもつに於ては皮䁈内層
細胞は明ら汃菱編し lipoid 含量も極めて少なくな り, hematoxylin-eosin 染色襟本では, X-zone 細胞に 酷似した外観を示して来る。しかし Ponceau-fuchsinanilin blue染色莫行つたものでは，これら細胞の細胞賀 は fasciculata 細胞と同様に青染妵られず，xylidineに よつて橙赤色に染色せられ，X-zone 細胞とは明らかに 染色性者買にする。尚て机ら細胞の配列状態は䒺状をな して，血管を伴つた少量の結合組織によつて隔離せられ る点から，これら内層の小型細胞は明らかに fasciculata 細胞の变北したものであるととが楒められる(Fig.9)。

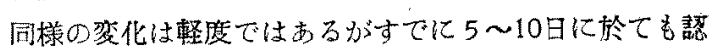
められる。

以上の観察は下垂体除去の影晸は Z. fasciculata 於て最も明瞭で，その変化は内層により早く現れるてと， 灰示す。

腹前立腺：正常成熟動物の上皮細胞は変異はあるが高 い円柱状で，絊胞筫は顆粒状で濃染性であり，核は円形 で基底近了偏在し，核より腺腔側の細胞質中に MOORE

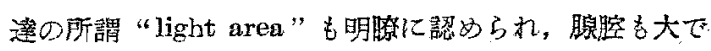

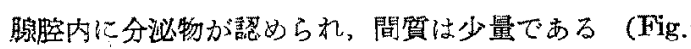

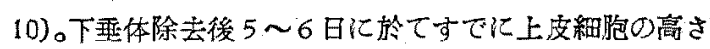
を減じ立方或はやや高い立方状となるが，上皮細胞の高 さにはかなりの变異か認められ， light areaは殆んど消 失し，紐狍貿はやや淡染性となる。腺腔の広さもやや退

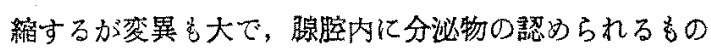
も出る。間質はやや增加を示す (Fig. 11)。乙れらの变 化は手術後の時間の経過とともに進行し，10〜15日後に 於ては，上皮細胞は帠平となり light area は完全に認 められなくなる。腺堙る退縮し，間質も增量する。ての 時期に於ては上皮絊胞の細胞筫は淡染性となり，核には pycnosis 漛の像を示すものも多数認められ，腺腔内脱 落細胞も諗められる(Fig. 12)。爾後はほぽての状態を 保つ。

精票：正常成熟雄に於ては腺腔内によく発達した稻壁 が認められ，腺腔は比較的狭い。上皮細胞法高い円柱状 紐胞で，核は円形乃至楕円形で基底近了偏在し，核之細 胞遊離縁との間には練胞質内に分泌顆粘及びてれを国む 所謂 “halo-like area” が明らかに認められ，細胞は好 染性を示し，腺腔内に多量の分泌物が認められる (Fig. 13)。手術後 5 6日於て解壁並びに上皮細胞の高さは

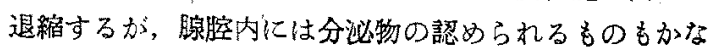
り存在する。上皮細胞の高さほ正常成热動物のものに比 し約 $1 / 2$ 近くまで诚じるが，分泌顆粒及びhalo-like area はまだ認められるものがある (Fig. 14)。術後10〜15日 以後では上皮細胞の高さは更に娍少し，正常の $1 / 2$ 或は それ以下になるが、まだ明らかな柱状を示す。細胞貿 
はやや淡染性となる。分泌顆粒は稀に認められるもの

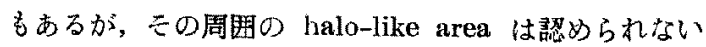

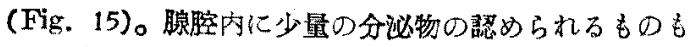
少数ながら存在する。手術後40日以上を経ても尚上皮細 胞はその高さを減しるが，まだ明らかな円杜状を示し，

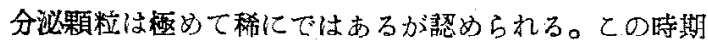
になれば腺腔内には分必物は殆んど楒められないなる。 手術50日以後では更に上皮の高さ索娍ずる。

\section{IV，考察}

マウスに於ける下垂体除去の実験報告は極めて少々，

LeBLoNd \& NELson ('37), Jones ('49 a,b, '50) 少見 られるのみで，前者によれば，ラッテに於けるとはは同

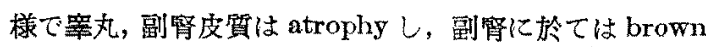
degeneration が見られるとのみで詳細な記载がない。 後者は未成整或は去劽マウスに於けるもので，主として X-zone に関する報告である。Jonss（50）によれば， 未成熟マウスで下釷体を除去すれば，2，glomerulosa の肥大を来し，Z. fasciculata の萎縮を来たすが,.下 垂体除去後長時日定経たものに於ては glomerulosa fasciculata この境界部に分裂像が認められるという。 下垂体除去の副生殖腺に対する影響に関しては報告は殆 んど見当らない。

ラッテに於ては等くの研究があり（SMrt十'30，SMITH

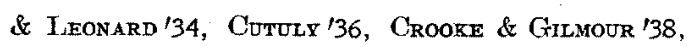
Smth '39, Deane \& Greep'46, Crafts'46, Leonard, PERLMAN \& KURZROK'48 その他), 睪丸, 副篮の萎縮退 化を認的ているが，睪丸に関しては，SMTH＆LEONARD （134）は下垂体除去後20日で精細管萎縮し精子は見られ なくなるが，gonia及 I -cyte は長期間分裂能力保つと いうが，間質細胞については副生殖腺の変化より間躓細 胞の退化を推定しているに過ぎない。LeOnard, PerLman \& KURZROK（'48）によれば下垂体除去後10日では精子 も多数存在し正常と大差なく，20日で精子は消失し，精 娘細胞も少引なり，24日では精娘細胞も消失し精上央の 萎縮萝しい。以上のラッテに於ける報告と比較すれば著 者達の結果は，精子の消失時期はラッテよりもやや掘い 'ことを示している。 SмтTH (39') によれば動物の種によ つて等丸の退綟速度に差があるから，著者達の結果は speciesによる差を示すものであろう。尚精細管の部位 により変化にかなりの差が見られ， spermatogenesis に wave の存在が考元られる。間細胞は下垂体除去後かな り早期茷能珽失或は低下を思わ寸る形態的变化を示し

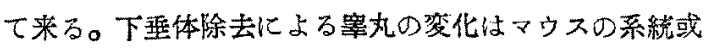
は個体による差か䛱められる。

本実験に使用したマウスは成熟雄であつて，副紫皮貿
の X-zone は消失鲳のものであり，下垂体除去㣪も $\mathrm{X}$ zone に関しては正常成熹雄上问栚に極々小数の遗残細

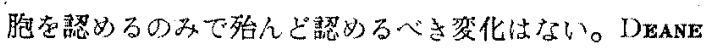
\& GREEP('46)はラツテに於て下垂体除去後 outer fasciculata 細胞の萎縮を来し皮貿全户の細胞はほぼ同一 の大きさになるとし, JoNEs (50') はマウスでglomerulosa は却つて肥大すること報告している。著者達の結 果も Jones と一致し glomerulosa はやや肥大するとと 認めた。最も顕著な変化として, fasciculata の萎縮及 びlipoid の淢少は多くの啡究者の珰めるところ上一致す ろが，乙の㚆化は内尸に於て強い傾向がある。fascicu一 lata 最内尸の細胞は葁縮し $\mathrm{X}$-zone 細胞類似の外観者示 すが, Ponceau-fuchsin anilin blue 染色標林に坽ける 細胞資の染色性及び細胞の配列状熊等から X-zone 細胞 とは明らかに区別出来る。皮質の初期変化は下垂体除去 後 4 日で琶められるというCROOKE \& GTLMOTR('38) と ほぼ一致し, 最大の变化仗 Sмmtн ('30), Cutuly ('36) とほば一致し30日で認められる。下垂体剔出による副腎 皮質の萎縮は細胞の菱縮による(SMTH $/ 30$, SHOMACKRR \& F IROR '34) との祱上, 細胞の退行変性による(CoLLIP'34, CROOKE \& GILMOUR '38) との説があるが, 著者達の研究に於ては両変化が認吼, 皮貿の退編は てれら両変化の協同作用によるものと考洸ら礼る。

下垂体除去後の副生殖腺の变化化関する報告仿極》て 少々，マウスに於ては藷者の知る限りでは皆無である。 著者迲の研究では腹前立腺及び精㢣に於ては下垂体除去 後5日ですでに変化が琹められ，10日後にはこの落化は 著明となり，腹前立腺に於ては上皮細胞は屚平さとなり light area 6 消失し，精覆上皮もその高さは正常の $1 / 2$ 以下となり halo-like area も消失し分泌顆粒も殆んも゙ 消失するが，精篗上皮細胞は未成熟動物の状態きでの完

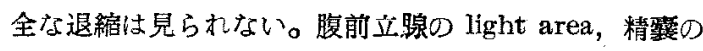
halo-like area $は$ Moore, Price \& Gallagher('30), Moore, Hughes \& Gallagere (130), Moore (136), Price (136), MoORe \& PrICE ('37, 138) 等の研究によ つて，男性ホルモンの鋭钽な indicator こなることが知 られている。著者達の実験に於ける下垂体除去後の睪丸 間細胞の変化と併せ考光れば，副生殖腺の変化は下垂体

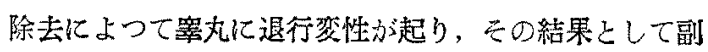
生殖腺の裂化を来したものであろうと考えら机る。

副生殖腺の退樎特に ventral prostate の変化は甚し 々，重量 dataはやや精密性を欠了うらみがあるが，上

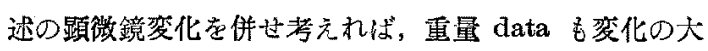
要は示すものと思われる。

\section{$\mathrm{V}$ 総 括}


成熟堆マウスに於て下垂体除去による生殖腺，副紫， 副生殖腺の変北を追究し次の結果を得た。

1 罳丸は著しく柔㳄となり充实感苍失心，色調もき や黄褐色を带び，重最も25 日以内に正常の $\%$ 以下とな る。

2 精紹管口径は手術後15２0日窅迄に急速に口径を 減ずるが，30日以後は減少はやや緩徐となる。精子は10 日頃迄柱相当多数が認められ，15日では少数の精細管内 に少数の精子が認められるに過ぎず，20２5日迄に完全 亿消失する。精娘細胞もはは平行して25日頃迄に消失 し，第二精母細胞も20〜25日迄治んど消失する。その 後は精上皮も薄尸となり精祖細胞と第一精母細胞のみと なるが，40日後にも尚分裂像が見られる。．

間紐胞は 5 日頃すでに変化が琶められ, pyenosis, karyorrhexis 等の 退行性变化, 細胞境界不明膫となり 全体汃強了黑染して来る。

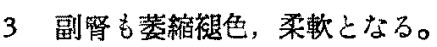

4 副等は手術後5日ですでに皮質に变化が瑟められ る。Z. fasciculata 細胞は葲縮し lipoid 方減少し, 乙 の棇化は fasciculata 内户に强い傾向が見られ，てれら

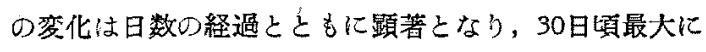
逢し以啳この状態孛保つ。Z. glomerulosa は却つて肥 大するが，变化は軽度である。X-zone 細胞仙皮檤境界

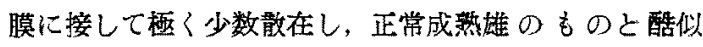
し，大きな变化は認めら机ない。领質にも著明な変化は 認められない。

5 副生殖腺も荽縮袙色し, 腹前立腺では特に甚し い。

6 副生殖腺にも手術後早期に変化が踗められ，10日 を過ぎれば腹前立腺上皮細胞は帠平となり light areaは 完全に消失する。精霆上皮細胞の高さも正常の約 $1 / 2$ 以下 に減し， halo-like area 訬消失するが，分泌顆粒は極め て少数ながら琶められる。

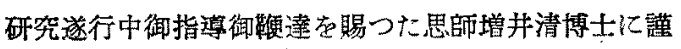
んで御礼申し上げ，種々御忠言を賜つた星冬四郎教授， 鈴木善祐助教授に表心より感謝する。尚本研究は文部省 科学研究費によつたものである。(1954，7．24，受付）

\section{文献}

1 Crooke, A. C. \& J. R. Gilmour (1938) : J. Pathol. \& Bact. , 47 ; 525-544

2 Cutuly, E. (1936) : Anat. Rec., 66; 119-122

3 Jones, I. C. (1949a) : Endocrinol. , 44; 427-438

4 Jowes, I. C. (1949b) : Endocrinol. , 45; 514-536

5 Jonks. I. C. (1950) : Am. J. Anat., 86; 371-403

6 Lebrond, C. P. et W. O. Nelson (1973) : C.R. de la Soc. de Biol., 124; 9-11

7 Leonard, S. I., P.L. Pertman \& R. Kurzrox (1948) : Endocrinol. , 42; 176-180

8 Moore, C.R. (1936) : Anat. Rec., 66; 1-9

9 Moore, C.R., W. Hughes \& T. F. Gallagher (1930) : Am. J. Anat., 45; 109-136

10 Moore, C.R., W. Hughes \& T. F. Gallagher (1937) : Endocrinol. , $21 ; 313-329$

11 Moore, O.R., W. Heghes \& T. F. Gallagher (1938) : Anat. Rec, , $71 ; 59-78$

12 Moore, C. R., D. Price \& T. F. Gallagher (1930) : Am. J. Anat, 45; 13-71

13 Price, D. (1936): Am. J. Anat. , 60; 79-127

14 Sedre, H. (1953) : Acta. Neuroveg., 6; 212-219

15. Shumacker, H. B. \& W. M. Firor (1934) :

Endocrinol., 18; 676-692

16 Sмrтt, P. E. (1930) : Am, J. Anat. , 45 ; 205-274

17 Smite, P. E. \& S. L. Leonard (1934): Anat.

Rec., 58 ; 145-174

18 Sмtтh, P. E. (1939) : Allen, Danforth \& Dorsy (1939) : Sex and Internal Secretione, 2nd Ed. 931-965より引用

\section{Résumé}

Twenty adult male albino mice were hypophysectomized, and sacrificed at various periods after this operation and ten normal litter mates were used as the controls. Animals used in this study were bcstrain mice and they were two to five months old at the operation time. Tissues were weighed and fixed by BoUT's and ZENKER-formol fluid, and stained with hematoxylin-eosin, HeIDENHAIN's iron hematoxylin (in testis)and modification of $\mathrm{Z}_{\text {INSSER's('51) Ponceau- }}$ fuchsin method (in adrenal). The results obtained were as follows.

1) Macroseopic observations: As time went by after hypophysectomy, the all organs studied underwent a significant regression in both their size and weight, and faded from their normal color, though testes became brownish yellow. Testes and adrenals became very flabby. The changes in organ weight were summarized in Table 1.

2) Histological observations :

Testis : As the diameters of seminiferous tubules have decreased rapidly by the twentieth day after hypophysectomy, this decreasing rate became very 
slow. There were many spermatozoa in tubules until the tenth day or so after operation, but after fifteenth day only few were found in several tubnles, and disappeared completely on the twentyfifth day.

Spermatids and II-spermatocytes also disappeared on the twentyfifth day or so after operation, then germinal epithelia became thinner, only spermatogonia and $I$-spermatocytes were observed in the tubules, but their mitotic figures could be seen even on the fortieth day or so after hypophysectomy. The degenerative changes of interstitial cells, such as pycnosis and karyorrhexis, were observed in the testes on the fifth day after hypophysectomy, and cell boundary became obscure, so the cells were stained black strongly in a mass by Heidenhain's iron bematoxylin.

Adrenal : Even on the fifth day after hypophysectomy the cells of Zona fasciculata atrophied and their lipid decreased in amounts, especially in the inner fasciculate zone, and as the days passed these changes became more prominent, and reached to the maximum on about thirtieth day after operation.
The cells of Zona glomerulosa were observed to become hypertrophic, but such changes were rather slight. The remnant cells of X-zone were observed seldom and scattered near the cortico-medullar boundary membrane. This structure is very similar to that of the normal abult male. No significant change was observed in the medulla.

Accessory reproductive organs : Though the epithelial cells of ventral prostate and seminal vesicle were typical columnar cells in normal adult controls, in experiments the epithelial cells of ventral prostate became flattened and the "Light area" in their cytoplasma disappeared completely by the tenth day after hypophysectomy. At that period the height of the epithelial cells of seminal vesicle was reduced to less than one-half of normal height and "Halo-like area" disappeared from their cytoplasma, but very few secretion granula were found in the cytoplasma between nucleus and free margin of the cells. These figures were also observed even on the fortieth day after operation. 


\section{Explanation of figures}

Figures 1-6 are testes fixed in Bouin's fluid, sectioned at $6 \mu$, and stained by Heidenhain's iron hematoxylin.

Figures 7-9 are adrenals fixed in Zenker formol, sectioned at $3 \mu$, and stained by modification of the Zinsser's Ponceau-fuchsin anilin blue method.

Figures 10-12 are ventral prostates and figures 13-15 are seminal vesicles, these glands are fixed in Bouin's fluid, sectioned at $3 \mu$, and stained by Delafield's hematoxylin-eosin.

Fig. 1. Normal adult mouse testis, for comparison with following figures.

Fig. 2. Testis of 5 days after hypophysectomy.

Fig. 3. Testis of 15 days after hypophysectomy.

Fig. 4. Testis of 20 days after hypophysectomy.

Fig. 5. Testis of 25 days after hypophysectomy.

Fig. 6. Testis of 40 days after hypophysectomy.

Fig. 7. Normal adult male mouse adrenal cortex.

Fig. 8. Adrenal cortex of 6 days after hypophysetomy.

Fig. 9. Adrenal cortex of 25 days after hypophysetomy, showing cytolytic figures in Z. fasciculata.

Fig. 10. Nomal adult mouse ventral prostate.

Fig. 11. Ventral prostate of 6 days after hypophysectomy.

Fig. 12. Ventral prostate of 25 days after hypophysctomy.

Fig. 13. Normal adult mouse seminal vesicle.

Fig. 14. Seminal vesicle of 6 days aiter bypophysectomy.

Fig. 15. Seminal vesicle of 38 days after hypophysectomy. 
西田・望月論文附图

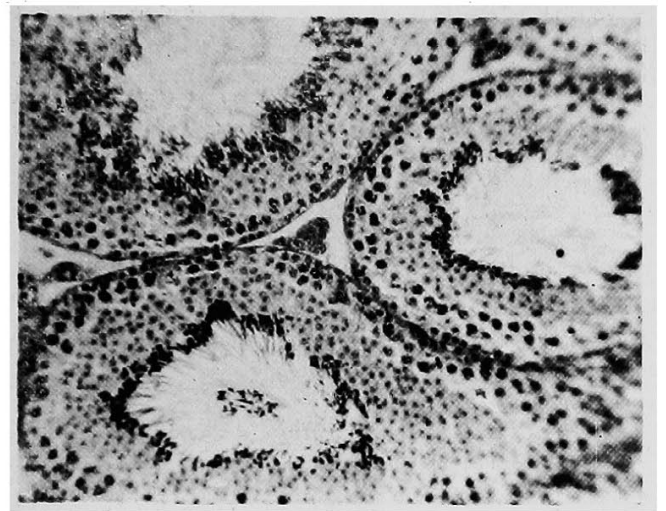

Fig. 1

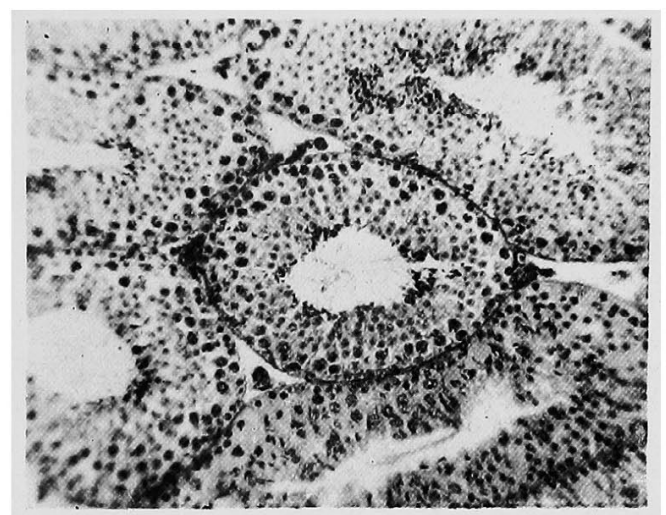

Fig. 2

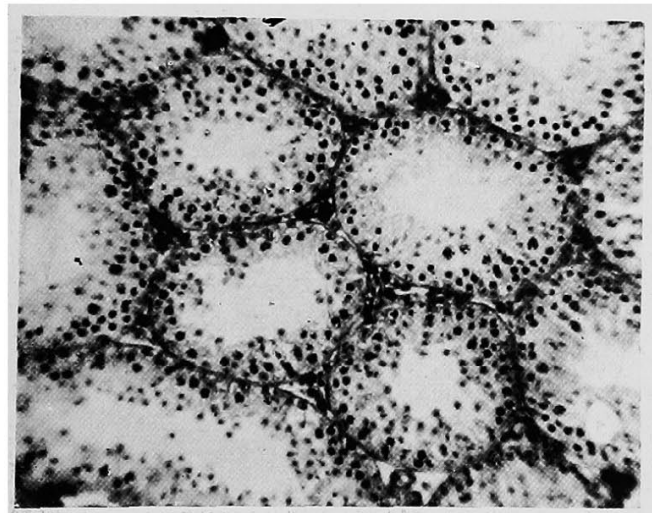

Fig. 3

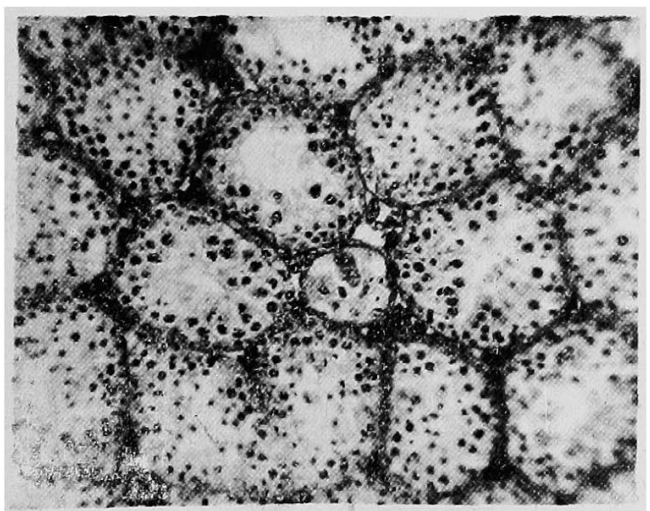

Fig. 5

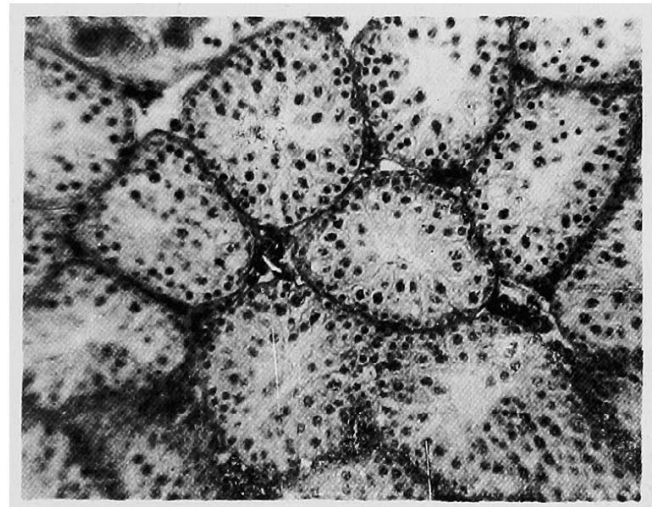

Fig. 4

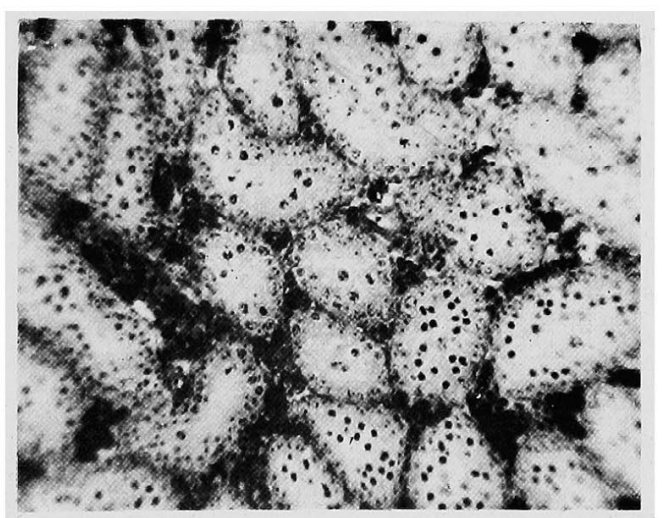

Fig. 6 
西田・望月論文附図

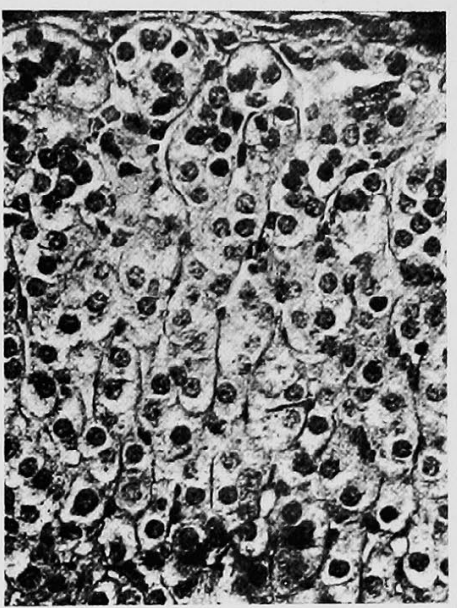

Fig. 7

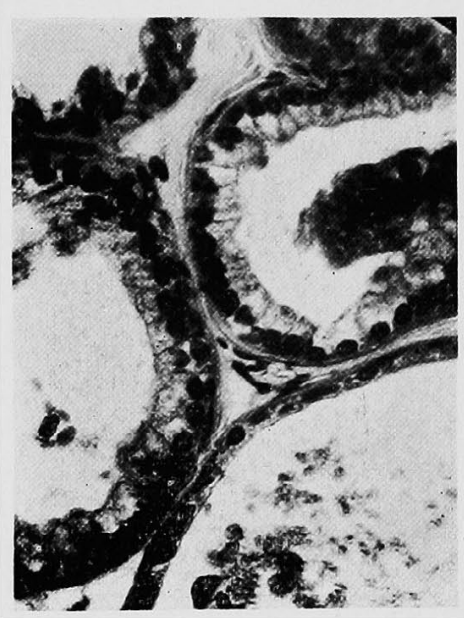

Fig. 10

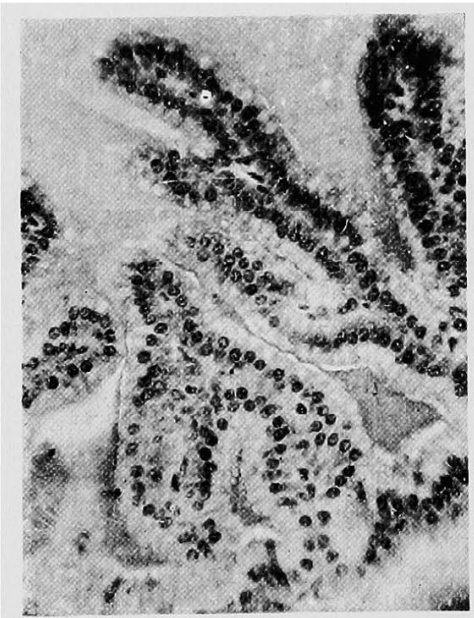

Fig. 13

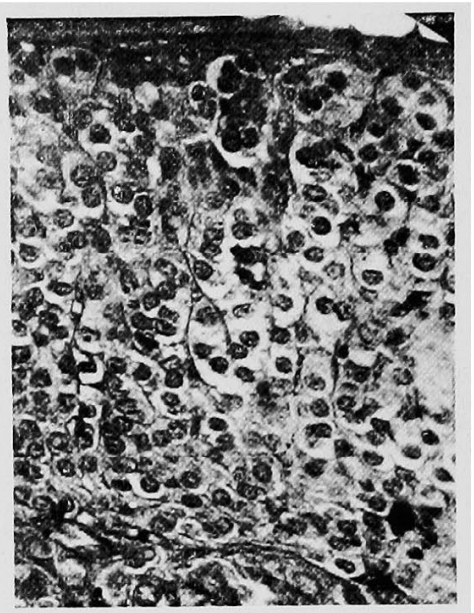

Fig. 8

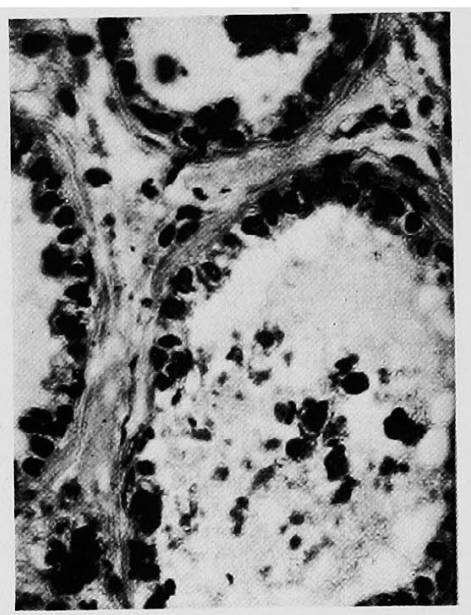

Fig. 11

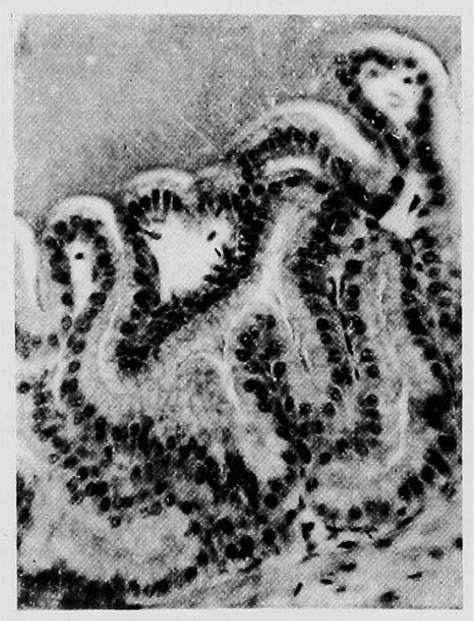

Fig. 14

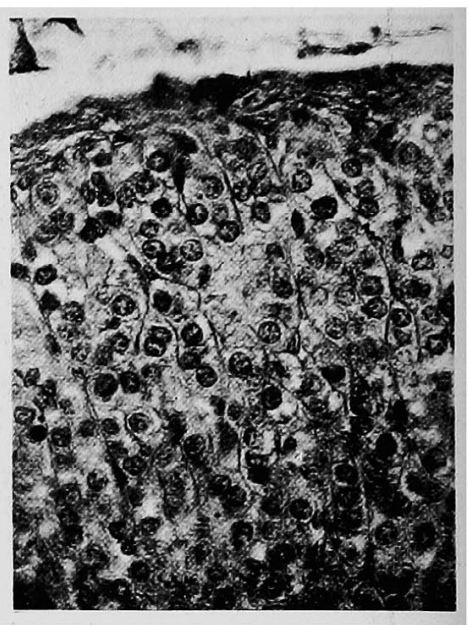

Fig. 9

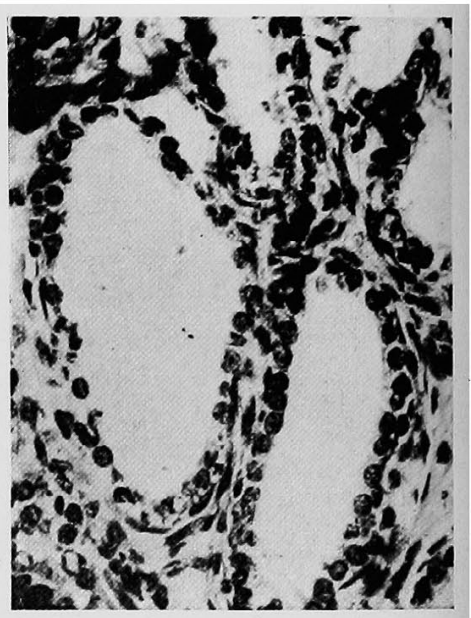

Fim. 12

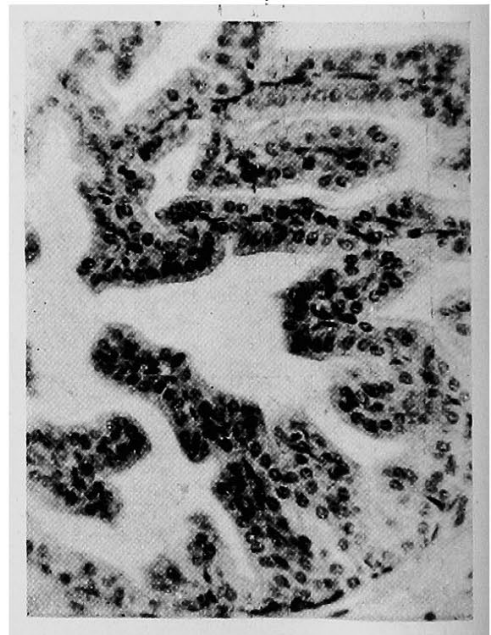

Fig. 15 